\title{
Perioperative outcomes after laparoscopic cholecystectomy in elderly patients: a systematic review and meta-analysis
}

\author{
Sivesh K. Kamarajah ${ }^{1,2}$ - Santhosh Karri ${ }^{3}$. James R. Bundred ${ }^{3} \cdot$ Richard P. T. Evans $^{4,5} \cdot$ Aaron Lin $^{3} \cdot$ Tania Kew $^{3}$. \\ Chinenye Ekeozor ${ }^{3} \cdot$ Susan L. Powell ${ }^{6} \cdot$ Pritam Singh $^{7,8} \cdot$ Ewen A. Griffiths ${ }^{4,5}$
}

Received: 12 April 2020 / Accepted: 25 June 2020 / Published online: 13 July 2020

(C) The Author(s) 2020

\begin{abstract}
Background Laparoscopic cholecystectomy is increasingly performed in an ever ageing population; however, the risks are poorly quantified. The study aims to review the current evidence to quantify further the postoperative risk of cholecystectomy in the elderly population compared to younger patients.

Method A systematic literature search of PubMed, EMBASE and the Cochrane Library databases were conducted including studies reporting laparoscopic cholecystectomy in the elderly population. A meta-analysis was reported in accordance with the recommendations of the Cochrane Library and PRISMA guidelines. Primary outcome was overall complications and secondary outcomes were conversion to open surgery, bile leaks, postoperative mortality and length of stay.

Results This review identified 99 studies incorporating 326,517 patients. Increasing age was significantly associated with increased rates of overall complications (OR 2.37, $\mathrm{CI}_{95 \%}$ 2.00-2.78), major complication (OR 1.79, $\left.\mathrm{CI}_{95 \%} 1.45-2.20\right)$, risk of conversion to open cholecystectomy (OR 2.17, $\mathrm{CI}_{95 \%} 1.84-2.55$ ), risk of bile leaks (OR 1.50, $\mathrm{CI}_{95 \%} 1.07-2.10$ ), risk of postoperative mortality (OR 7.20, $\mathrm{CI}_{95 \%} 4.41-11.73$ ) and was significantly associated with increased length of stay (MD 2.21 days, $\left.\mathrm{CI}_{95 \%} 1.24-3.18\right)$.

Conclusion Postoperative outcomes such as overall and major complications appear to be significantly higher in all age cutoffs in this meta-analysis. This study demonstrated there is a sevenfold increase in perioperative mortality which increases by tenfold in patients $>80$ years old. This study appears to confirm preconceived suspicions of higher risks in elderly patients undergoing cholecystectomy and may aid treatment planning and informed consent.
\end{abstract}

Keywords Cholecystectomy $\cdot$ Elderly $\cdot$ Outcomes $\cdot$ Laparoscopic

Over 66,000 cholecystectomies are performed each year in the UK costing over $£ 110$ million to the National Health Service $[1,2]$. The majority of these cases are now done laparoscopically, owing to significantly lower rates of morbidity and mortality compared to conventional open

Sivesh K. Kamarajah and Santhosh Karri have contributed equally as co-first authors.

James R. Bundred and Richard P. T. Evans have contributed equally as co-second authors.

Electronic supplementary material The online version of this article (https://doi.org/10.1007/s00464-020-07805-z) contains supplementary material, which is available to authorised users.

Ewen A. Griffiths

ewen.griffiths@uhb.nhs.uk

Extended author information available on the last page of the article surgery. Recently, a national multicentre study highlighted that $96 \%$ of cases are done laparoscopically, establishing laparoscopic cholecystectomy as mainstay management for various benign gallbladder diseases [3, 4]. Biliary colic or acute cholecystitis accounts for $>70 \%$ of the indications for performing a cholecystectomy.

With an ageing population, demands for surgery are expected to rise over the next decade with associated increasing frailty $[5,6]$. In parallel, it is estimated that increasing numbers of elderly patients will present with gallstone disease [7, 8], and it is thought that patients aged 80-89 years account for $28 \%$ and $42 \%$ of male and female patients, respectively $[8,9]$. Since age is associated with existence of multiple comorbidities and reduced functional reserve, it is thought that operating on elderly patients could be associated with an increased risk of complications [10-12]. Despite this, elderly patients may still undergo laparoscopic 
cholecystectomy. Many studies evaluating outcomes of laparoscopic cholecystectomy in their definition of elderly patients versus younger patients have shown that increasing age leads to higher conversion rates, more complications and a longer hospital stay [7-10].

Despite this, current literature on definition of an elderly population in regard to outcomes following laparoscopic cholecystectomy is heterogeneous. Hence, counselling elderly patients regarding morbidity and mortality of laparoscopic cholecystectomy is difficult. To date, current evidence is limited to cohort studies and no meta-analysis characterising the impact of age on postoperative complications following laparoscopic cholecystectomy exists. Therefore, this study aimed to perform a systematic review and metaanalysis to summarise postoperative outcomes of elderly patients undergoing laparoscopic cholecystectomy.

\section{Methods}

This paper is reported according to the PRISMA guidelines [13] and was prospectively registered with the PROSPERO database (Registration CRD42019125343). This study did not require approval by the Institutional Review Board as this was a systematic review of current literature and no patient consent was required. There was deviation from the protocol with additional analyses by urgency of surgery and the use of ROBINS-I for study quality assessment.

\section{Search strategy}

A systematic search of PubMed, EMBASE and the Cochrane Library databases was conducted on the 1 November 2018 by two independent investigators (SKK, SK). The search terms used were 'cholecystectomy' or 'laparoscopic', and 'treatment outcome' or 'complications' or 'intraoperative complications' or 'postoperative complication', and 'elderly' or 'octogenarian' or 'frail' individually or in combination. Search terms used for this review are presented as shown in Supplementary Table 1. The 'related articles' function was used to broaden the search, and all citations were considered for relevance. A manual search of reference lists in recent reviews and eligible studies was also undertaken.

\section{Inclusion and exclusion criteria}

The inclusion criteria were (1) studies reporting comparative analysis of laparoscopic cholecystectomy in elderly patients; (2) published in the English language. Studies were still included even if all the relevant outcome data were not provided. Exclusion criteria were (1) conference abstracts, systematic reviews, meta-analyses and case reports $(<5$ patients); (2) any studies that did not report the outcomes of the surgery numerically. Two independent authors (RSK, SK) excluded duplicates and independently reviewed the titles, abstracts and full articles of the studies identified by the literature search. Where the full article was not available, in paper or electronic form, the article was excluded. Major reviews were manually searched to obtain any other potentially relevant studies. The authors discussed any cases which presented any differences.

\section{Study outcomes}

The primary outcome measures were overall complications (Grade I-V) and major complications ( $\geq$ Grade III) reported according to Clavien-Dindo Classification [14]. Secondary outcomes were conversion to open surgery, bile leaks, perioperative mortality and length of hospital stay.

\section{Data extraction}

Three authors extracted data independently and reviewed the data for any discrepancies. The data collected included study characteristics (authors, year of publication, country of origin, patient number, definition of elderly, type of study), indications for surgery and outcome measures (overall and major complications, major complications, conversion, bile leaks, perioperative mortality, length of hospital stay).

\section{Assessment of methodological quality}

Four independent authors (SKK, RSK, CE, TC) assessed the methodological quality using the risk of bias in nonrandomised studies of interventions (ROBINS-I) [15]. The ROBINS-I assessed each study on seven distinct domains through which bias might be introduced. These domains are divided according to pre-intervention (bias due to confounding and bias in selection of participants into the study), at intervention (bias in classification of interventions), and post-intervention (bias due to deviations from intended interventions, bias due to missing data, bias in measurement of outcomes and bias in selection of the reported result). Each of these seven domains is graded according to low, moderate, critical, serious or no information.

\section{Statistical methods}

This systematic review and meta-analysis was conducted in accordance with the recommendations of the Cochrane Library and PRISMA guidelines [13]. For binary variables, analysis was performed by calculating the odds ratio (OR). For continuous data, analysis was performed to calculate the cumulative mean difference (MD) with $95 \%$ confidence intervals $\left(\mathrm{CI}_{95 \%}\right)$. The random effects, the DerSimonian-Laird method, was used for the meta-analysis of 
outcomes. Heterogeneity between studies was assessed using the $I_{2}$ value in order to determine the degree of variation not attributable to chance alone. $I_{2}$ values were considered to represent low, moderate and high degrees of heterogeneity where values were $<25 \%, 25-75 \%$ and $>75 \%$, respectively. Assessment of small study effects was carried out by visual assessment of funnel plots and Egger regressions. Stratified analyses were performed by urgency of surgery (i.e. elective and emergency) for each postoperative outcome. Statistical significance was considered when $p<0.05$. Statistical analyses were performed using the RevMan 5.3 software (Copenhagen: The Nordic Cochrane Centre, The Cochrane Collaboration, 2011) and R statistical software (Version 3.5.2, R Foundation for Statistical Computing, Vienna, Austria) as previously described $[16,17]$.

\section{Results}

\section{Study characteristics}

This study included 99 studies ( $n=326,517$ patients) reported according to the PRISMA guidelines as shown in Fig. 1. Baseline characteristics of studies are presented in Supplementary Table 2. Studies identified were from North America $(n=28)$, Asia $(n=31)$ and Europe $(n=39)$. Indication for surgery was reported only in 77 studies. Urgency of cholecystectomy were reported in 90 studies ( $n=303,463$ patients), of which $7 \%(n=19,754)$ were elective cases and $67 \%(n=203,924)$ were emergency cases. In this study, 52 studies were comparative studies.
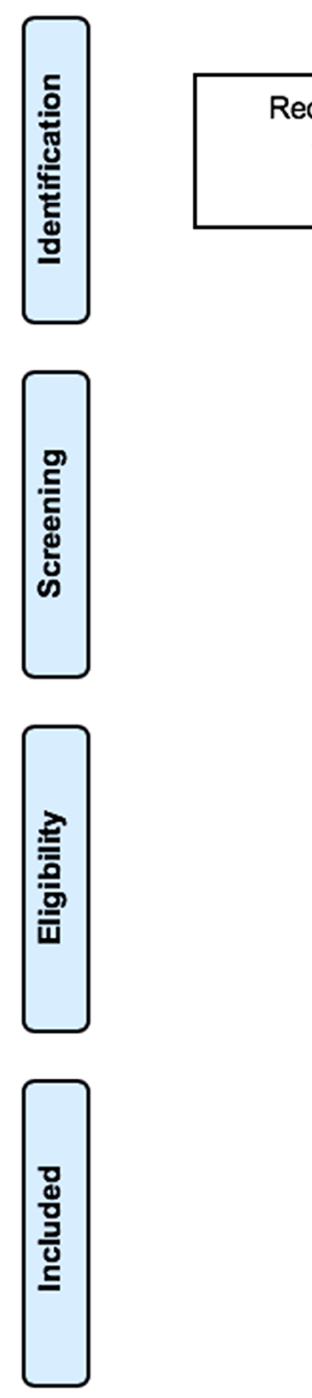

Records identified through database searching $(n=3026)$

Records after duplicates removed $(n=2512)$

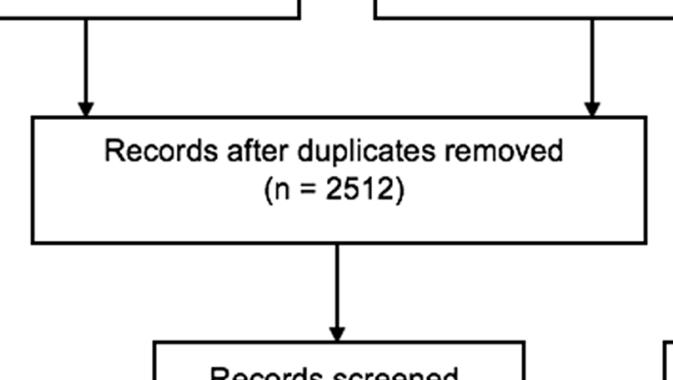

Additional records identified through other sources $(n=0)$

$(n=2512)$

Records excluded ( $n=2383$ )

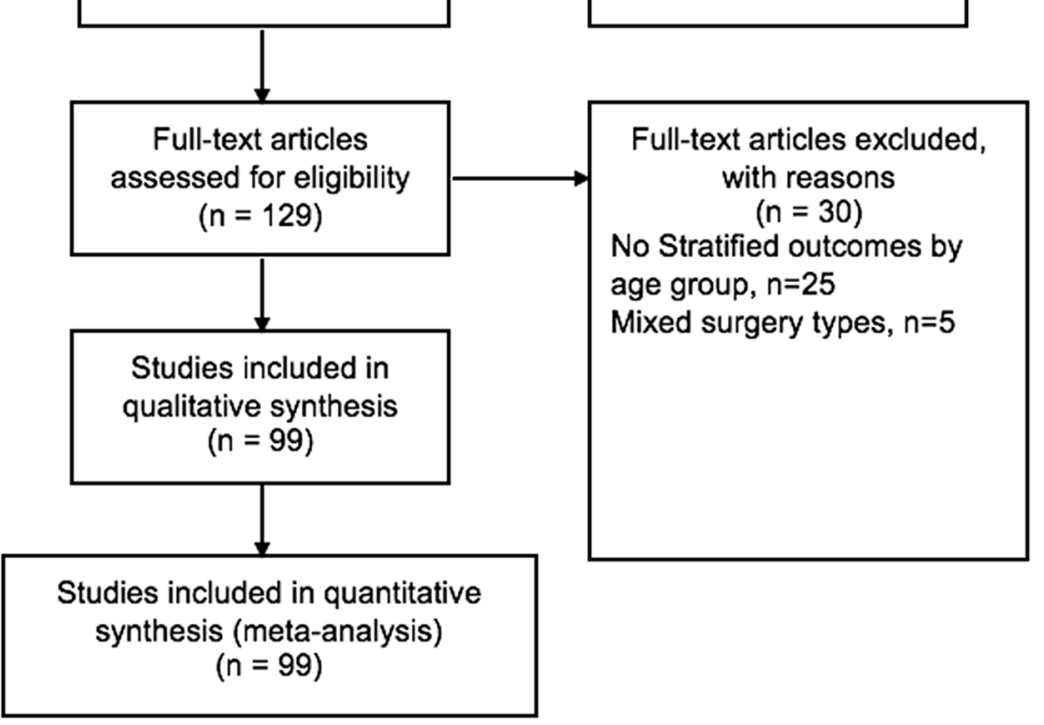

Fig. 1 PRISMA diagram of included studies 


\section{Reporting standards and methodological quality}

Study quality was assessed using ROBINS-I for comparative studies, with majority of studies $(78 \%, n=77 / 99)$ deemed as overall low risk of bias (Supplementary Table 3). There was significant variation in cut-off ages used to define elderly populations with age $\geq 60$ ( $n=8$ studies), $\geq 65$ ( $n=39$ studies), $\geq 70$ ( $n=14$ studies $), \geq 75$ ( $n=11$ studies $), \geq 80$ ( $n=22$ studies) the most commonly used. Studies were pooled into subgroups according to age cut-off value.

\section{Overall complications}

Impact of increasing age on overall complications was reported in 48 studies, including 49,215 patients. Overall, increasing age was significantly associated with increased rates of overall complications (OR 2.37, $\mathrm{CI}_{95 \%} 2.01-2.78$, $I_{2}=56 \%$ ) (Supplementary Fig. 1). Overall complication rates were significantly increased in age subgroups: $\geq 65$ years (OR 2.63, $\mathrm{CI}_{95 \%} 1.96-3.54, I_{2}=70 \%$ ), $\geq 70$ years $(\mathrm{OR}$ $\left.1.76 \mathrm{CI}_{95 \%} 1.30-2.39, I_{2}=0 \%\right), \geq 75$ years $\left(\mathrm{OR} 2.26, \mathrm{CI}_{95 \%}\right.$ $\left.1.65-3.10, I_{2}=0 \%\right)$ and $\geq 80$ (OR 2.71, $\mathrm{CI}_{95 \%} 1.83-3.99$, $I_{2}=52 \%$ ) (Table 1, Fig. 2). When stratified by urgency, increasing age was associated with significantly higher overall complications for elective (OR 2.46, $\mathrm{CI}_{95 \%}$ 1.63-3.71, $I_{2}=38 \%$ ) and emergency (OR 1.98, $\mathrm{CI}_{95 \%} 1.33-2.94$, $I_{2}=48 \%$ ) laparoscopic cholecystectomy (Table 2).

\section{Major complications}

Impact of increasing age on major complications was reported in 14 studies, including 34,748 patients. Increasing age was associated with significantly higher rates of major postoperative complications (OR 1.79, $\mathrm{CI}_{95 \%}$ 1.45-2.20, $I_{2}=34 \%$ ) (Supplementary Fig. 2). Major complication rates were significantly increased in subgroups: $\geq 65$ years (OR $\left.1.51, \mathrm{CI}_{95 \%} 1.38-1.65, I_{2}=0 \%\right)$ and $\geq 80$ years (OR 1.95, $\mathrm{CI}_{95 \%}$ 1.65-2.29, $I_{2}=0 \%$ ) (Supplementary Fig. 3). Since there was only one study reporting outcomes for major complications elective and emergency laparoscopic cholecystectomy, subgroup analyses were not possible (Table 2).

\section{Conversion to open surgery}

Impact of increasing age on conversion to open cholecystectomy was reported in 53 studies, including 59,173 patients. Overall, increasing age was significantly associated with increased odds of conversion to open cholecystectomy (OR 2.17, $\mathrm{CI}_{95 \%}$ 1.84-2.55, $I_{2}=56 \%$ ) (Supplementary Fig. 4). Conversion to open cholecystectomy was significantly increased in subgroups with the following age cut-offs: $\geq 65$ (OR 2.62, $\mathrm{CI}_{95 \%} 1.97-3.49, I_{2}=63 \%$ ), $\geq 75$ (OR 2.04, $\left.\mathrm{CI}_{95 \%} 1.54-2.69, I_{2}=0 \%\right), \geq 80\left(\mathrm{OR} 2.48, \mathrm{CI}_{95 \%}\right.$
1.97-3.12, $I_{2}=13 \%$ ) (Table 1, Supplementary Fig. 5). When stratified by urgency, increasing age was associated with significantly higher odds for conversion for elective (OR 2.48, $\mathrm{CI}_{95 \%} 1.71-3.59, \mathrm{I}_{2}=0 \%$ ) and emergency (OR 2.28, $\mathrm{CI}_{95 \%}$ 1.39-3.75, $I_{2}=58 \%$ ) laparoscopic cholecystectomy (Table 2).

\section{Bile leaks}

Impact of increasing age on bile leaks was reported in 30 studies, including 42,765 patients. Overall, increasing age was significantly associated with increased rates of bile leaks (OR 1.50, $\mathrm{CI}_{95 \%}$ 1.07-2.10, $I_{2}=0 \%$ ) (Supplementary Fig. 6). However, bile leaks were not increased in studies reporting age in all age cut-offs (Table 1, Supplementary Fig. 7). When stratified by urgency, increasing age was not associated with higher rates of bile leaks for elective (OR 0.56, $\mathrm{CI}_{95 \%} 0.12-2.69, \mathrm{I}_{2}=0 \%$ ) and emergency (OR 1.28, $\mathrm{CI}_{95 \%}$ $0.75-2.18, I_{2}=0 \%$ ) laparoscopic cholecystectomy (Table 2).

\section{Postoperative mortality}

Impact of increasing age on postoperative mortality was reported in 50 studies, including 78,404 patients. Overall, increasing age was significantly associated with increased rates of postoperative mortality (OR 7.20, $\mathrm{CI}_{95 \%} 4.41-11.73$, $I_{2}=59 \%$ ) (Supplementary Fig. 8). Postoperative mortality rates were significantly increased in all age cut-off subgroups: $\geq 65$ (OR 5.17, $\mathrm{CI}_{95 \%} 2.48-10.77, I_{2}=56 \%$ ), $\geq 70$ (OR 4.86, $\left.\mathrm{CI}_{95 \%} 1.04-22.75, \mathrm{I}_{2}=0 \%\right), \geq 75\left(\mathrm{OR} 6.09, \mathrm{CI}_{95 \%}\right.$ 1.61-23.02, $I_{2}=2 \%$ ), $\geq 80$ (OR 10.20, $\mathrm{CI}_{95 \%} 4.97-20.92$, $I_{2}=32 \%$ ) (Fig. 3). When stratified by urgency, increasing age was associated with significantly higher rates of postoperative mortality for elective (OR 13.34, $\mathrm{CI}_{95 \%}$ 2.07-85.92, $I_{2}=0 \%$ ) and emergency (OR 5.54, $\mathrm{CI}_{95 \%} 1.96-15.70$, $I_{2}=0 \%$ ) laparoscopic cholecystectomy (Table 2).

\section{Length of stay}

Impact of increasing age on length of stay following cholecystectomy was reported in 24 studies, including 10,997 patients. Overall, increasing age was significantly associated with increased length of stay (Mean difference (MD): 2.21, $\mathrm{CI}_{95 \%}$ 1.24-3.18, $I_{2}=99 \%$ ) (Supplementary Fig. 9). Length of stay was significantly increased in age cut-off subgroups: $\geq 65$ (MD 2.33, $\mathrm{CI}_{95 \%} 1.10-3.56, I_{2}=96 \%$ ), $\geq 70\left(\mathrm{MD} 3.37, \mathrm{CI}_{95 \%} 0.28-6.46, I_{2}=98 \%\right)$ and $\geq 80(\mathrm{MD}$ $1.33, \mathrm{CI}_{95 \%} 0.54-2.11, I_{2}=83 \%$ ) (Table 1, Supplementary Fig. 10). When stratified by urgency, increasing age was associated with significantly longer length of stay for elective (MD 1.84, $\mathrm{CI}_{95 \%} 1.27-2.41, I_{2}=64 \%$ ) and emergency (MD 2.63, $\mathrm{CI}_{95 \%} 1.13-4.14, I_{2}=88 \%$ ) laparoscopic cholecystectomy (Table 2). 
Table 1 Summary of postoperative outcomes in patients undergoing laparoscopic cholecystectomy

\begin{tabular}{|c|c|c|c|c|c|}
\hline Outcomes & Studies, $n$ & Patients, $n$ & $\begin{array}{l}\text { Odds ratio/mean differ- } \\
\text { ence* }(95 \% \mathrm{CI})\end{array}$ & $p$ value & $I^{2}$ \\
\hline \multicolumn{6}{|l|}{ Overall complications } \\
\hline$\geq 60$ vs $<60$ years & 3 & 1107 & $1.86(0.84-4.11)$ & 0.1 & 75 \\
\hline$\geq 65$ vs $<65$ years & 15 & 32,927 & $2.63(1.96-3.54)$ & $<0.001$ & 70 \\
\hline$\geq 70$ vs $<70$ years & 8 & 2453 & $1.76(1.30-2.39)$ & $<0.001$ & 0 \\
\hline$\geq 75$ vs $<75$ years & 7 & 4299 & $2.26(1.65-3.10)$ & $<0.001$ & 0 \\
\hline$\geq 80$ vs $<80$ years & 14 & 6394 & $2.71(1.83-3.99)$ & $<0.001$ & 52 \\
\hline \multicolumn{6}{|l|}{ Major complications } \\
\hline$\geq 60$ vs $<60$ years & 0 & & - & - & - \\
\hline$\geq 65$ vs $<65$ years & 2 & 15,044 & $1.51(1.38-1.65)$ & $<0.001$ & 0 \\
\hline$\geq 70$ vs $<70$ years & 3 & 831 & $2.16(0.71-6.53)$ & 0.2 & 71 \\
\hline$\geq 75$ vs $<75$ years & 2 & 919 & $1.88(0.35-10.14)$ & 0.5 & 0 \\
\hline$\geq 80$ vs $<80$ years & 7 & 17,954 & $1.95(1.65-2.29)$ & $<0.001$ & 0 \\
\hline \multicolumn{6}{|l|}{ Conversion to Open } \\
\hline$\geq 60$ vs $<60$ years & 3 & 1107 & $1.52(0.91-2.50)$ & 0.1 & 0 \\
\hline$\geq 65$ vs $<65$ years & 18 & 27,122 & $2.62(1.97-3.49)$ & $<0.001$ & 63 \\
\hline$\geq 70$ vs $<70$ years & 6 & 1695 & $1.50(0.54-4.13)$ & 0.4 & 78 \\
\hline$\geq 75$ vs $<75$ years & 7 & 4519 & $2.04(1.54-2.69)$ & $<0.001$ & 0 \\
\hline$\geq 80$ vs $<80$ years & 17 & 22,340 & $2.48(1.97-3.12)$ & $<0.001$ & 13 \\
\hline \multicolumn{6}{|l|}{ Bile Leaks } \\
\hline$\geq 60$ vs $<60$ years & 2 & 442 & $0.56(0.12-2.69)$ & 0.5 & 0 \\
\hline$\geq 65$ vs $<65$ years & 10 & 20,889 & $1.43(0.93-2.23)$ & 0.1 & 0 \\
\hline$\geq 70$ vs $<70$ years & 4 & 1189 & $1.60(0.62-4.13)$ & 0.3 & 0 \\
\hline$\geq 75$ vs $<75$ years & 5 & 3127 & $1.78(0.49-6.41)$ & 0.4 & 0 \\
\hline$\geq 80$ vs $<80$ years & 9 & 17,118 & $2.05(0.87-4.84)$ & 0.1 & 0 \\
\hline \multicolumn{6}{|c|}{ Postoperative mortality } \\
\hline$\geq 60$ vs $<60$ years & 2 & 442 & - & - & - \\
\hline$\geq 65$ vs $<65$ years & 16 & 49,962 & $5.17(2.48-10.77)$ & $<0.001$ & 56 \\
\hline$\geq 70$ vs $<70$ years & 6 & 1583 & $4.86(1.04-22.75)$ & 0.045 & 0 \\
\hline$\geq 75$ vs $<75$ years & 9 & 4795 & $6.09(1.61-23.02)$ & 0.008 & 2 \\
\hline$\geq 80$ vs $<80$ years & 15 & 21,185 & $10.20(4.97-20.92)$ & $<0.001$ & 32 \\
\hline \multicolumn{6}{|l|}{ Length of Stay, days } \\
\hline$\geq 60$ vs $<60$ years & - & & - & - & - \\
\hline$\geq 65$ vs $<65$ years & 7 & 2920 & $2.33(1.10-3.56)$ & $<0.001$ & 96 \\
\hline$\geq 70$ vs $<70$ years & 5 & 1616 & $3.37(0.28-6.46)$ & 0.032 & 98 \\
\hline$\geq 75$ vs $<75$ years & 4 & 2933 & $1.08(-0.28-2.44)$ & 0.1 & 92 \\
\hline$\geq 80$ vs $<80$ years & 7 & 3173 & $1.33(0.54-2.11)$ & $<0.001$ & 83 \\
\hline
\end{tabular}

*Mean difference were used for the presentation of length of stay data

\section{Publication biases}

Egger regression testing suggested publication biases were minimal for reporting of major complications $(p=0.314$, Supplementary Fig. 11), conversion to open $(p=0.352$, Supplementary Fig. 12), bile leaks ( $p=0.589$, (Supplementary Fig. 13) and postoperative mortality $(p=0.172$,
(Supplementary Fig. 14), and length of stay ( $p=0.728$, Supplementary Fig. 15). Egger regression testing for publication bias was significant for reporting of overall complications ( $p=0.004$, Supplementary Fig. 16). Subgroup analyses showed that publication biases were present in the subgroup of studies reporting age $>65$ as a cut-off $(p=0.0012)$ and not in any of the other subgroups. 


\begin{tabular}{|c|c|c|c|c|c|}
\hline \multirow[b]{2}{*}{$\mathbf{A}$} & \multirow[b]{2}{*}{ Study } & \multicolumn{2}{|c|}{ Elderly } & \multicolumn{2}{|c|}{ Non-Elder } \\
\hline & & Events & Total & Events & To \\
\hline & Nazeer 2012 & 13 & 60 & 26 & \\
\hline & Bhandari 2017 & 14 & 78 & 24 & \\
\hline & Ekici 2018 & 21 & 127 & 26 & \\
\hline & Random effects model & & 265 & & \\
\hline & Heterogeneity: $I^{2}=75 \%, \mathrm{~T}^{2}=$ & $44, p=$ & & & \\
\hline
\end{tabular}

Heterogeneity: $I^{2}=75 \%, \mathrm{~T}^{2}=0.3644, p=0.02$

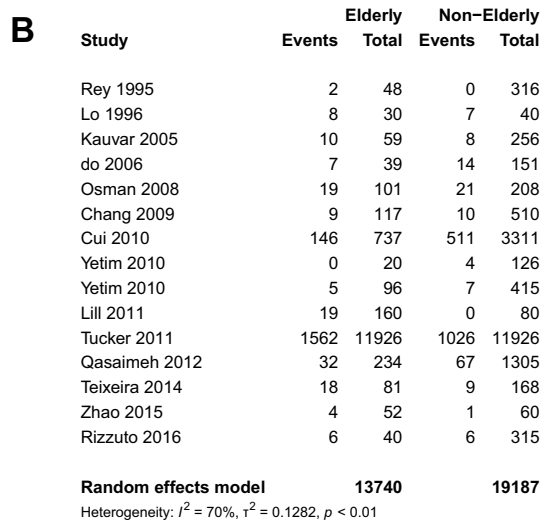

\section{Study}

Ido 1995

Mayol 1997

Paganini 2002

Bingener 2003

Annamaneni 2005

Yetkin 2009

Fujikawa 2012

Ambe 2015

Random effects model

Heterogeneity: $I^{2}=0 \%, \mathrm{~T}^{2}=0, p=0.63$

Elderly Non-Elderly Events Total Events Total

$\begin{array}{rrrr}13 & 57 & 80 & 655 \\ 12 & 61 & 11 & 97 \\ 9 & 77 & 28 & 207 \\ 34 & 230 & 12 & 165 \\ 5 & 29 & 1 & 17 \\ 9 & 68 & 51 & 527 \\ 5 & 49 & 2 & 62 \\ 18 & 74 & 11 & 78\end{array}$

645

1808
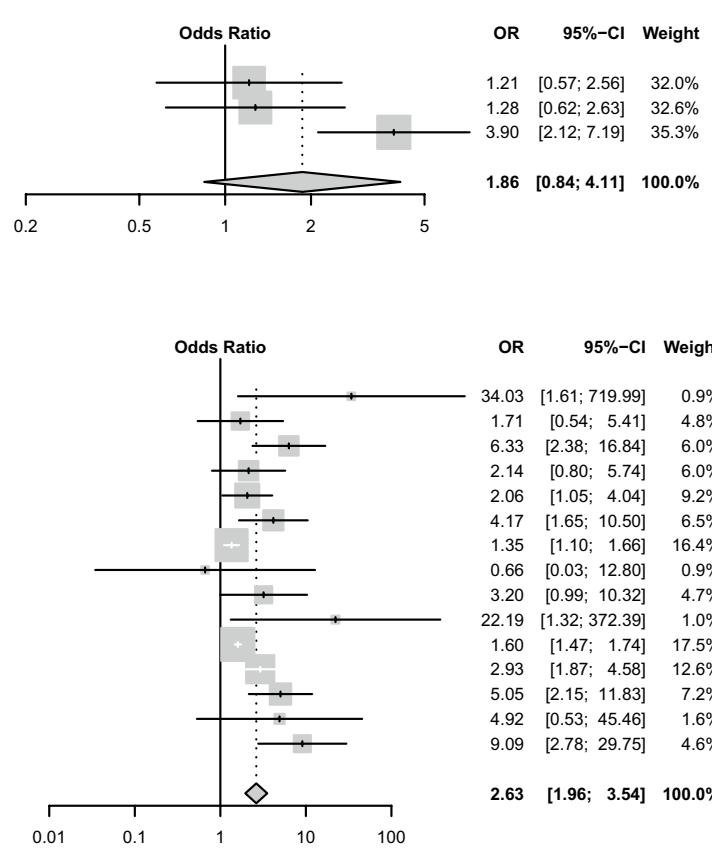

OR $\quad 95 \%-\mathrm{Cl}$ Weight

$34.03[1.61 ; 719.99] \quad 0.9 \%$ $1.71 \quad[0.54 ; 5.41] \quad 4.8 \%$ $6.33 \quad[2.38 ; 16.84] \quad 6.0 \%$ $2.14 \quad[0.80 ; 5.74] \quad 6.0 \%$ $2.06 \quad[1.05 ; 4.04] \quad 9.2 \%$ $4.17 \quad[1.65 ; 10.50] \quad 0.5 \%$ $1.35 \quad[1.10 ; 1.66] \quad 16.4 \%$ $0.66 \quad[0.03,12.80] \quad 0.9 \%$ $3.20 \quad[0.99 ; 10.32] \quad 4.7 \%$ $22.19[1.32 ; 372.39] \quad 1.0 \%$ $1.60 \quad[1.47 ; 1.74] \quad 17.5 \%$ $2.93 \quad[1.87 ; 4.58] \quad 12.6 \%$ $5.05 \quad[2.15 ; 11.83] \quad 7.2 \%$ $4.92 \quad[0.53 ; 45.46] \quad 1.6 \%$ $9.09 \quad[2.78 ; 29.75] \quad 4.6 \%$

$2.63[1.96 ; 3.54] 100.0 \%$

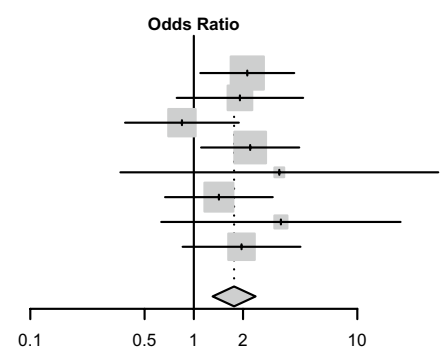

OR $\quad 95 \%-\mathrm{Cl}$ Weight

$2.12 \quad[1.10 ; 4.11] \quad 20.9 \%$ $1.91 \quad[0.79 ; 4.66] \quad 11.5 \%$ $0.85 \quad[0.38 ; 1.89] \quad 14.2 \%$ $2.21 \quad[1.11 ; 4.42] \quad 19.1 \%$ $3.33[0.36 ; 31.26] \quad 1.8 \%$ $1.42 \quad[0.67 ; 3.04] \quad 15.9 \%$ $3.41 \quad[0.63 ; 18.39] \quad 3.2 \%$ $1.96 \quad[0.85 ; 4.49] \quad 13.3 \%$

$1.76[1.30 ; 2.39] \quad 100.0 \%$

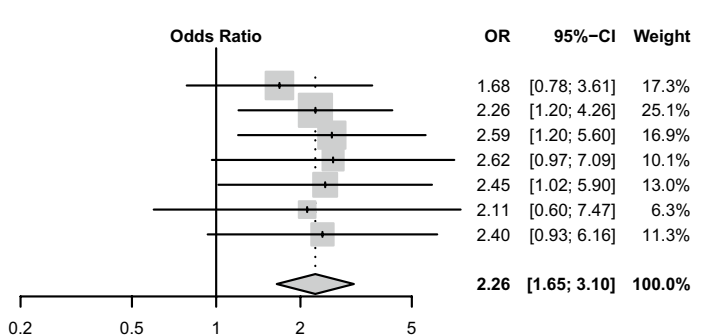
Non-Elderly
Events Total Events Tota

Study

Firilas 1996

Pessaux 2000

Kirshtein 2008

Osman 2008

Polychronidis 2008

Su 2009

$\begin{array}{llll}14 & 102 & 50 & 761\end{array}$

$\begin{array}{llll}13 & 42 & 27 & 183\end{array}$

$\begin{array}{llll}6 & 23 & 34 & 286\end{array}$

$\begin{array}{rrrr}6 & 153 & 37 & 2259 \\ 6 & 17 & 8 & 39\end{array}$

Lill 2011$$
478
$$

3821

Random effects model
Heterogeneity: $I^{2}=0 \%, \mathrm{~T}^{2}=0, p=0.99$
0.2

Elderly Non-Elderly

E Study

Maxwell 1998

Brunt 2001

Bingener 2003

Kwon 2006

Costi 2007

Pavlidis 2008

Chang 2009

Kim 2009

Leardi 2009

Lee 2013

Mauro 2014

Peker 2014

Wakasugi 2017

Yokota 2018

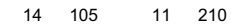

$\begin{array}{llll}14 & 105 & 11 & 210\end{array}$

$\begin{array}{llll}8 & 49 & 38 & 346\end{array}$

$\begin{array}{llll}1 & 45 & 10 & 471\end{array}$

$\begin{array}{rrrr}6 & 27 & 5 & 133 \\ 3 & 21 & 39 & 1242 \\ 3 & 17 & 16 & 610\end{array}$

$\begin{array}{rrrr}3 & 17 & 16 & 610\end{array}$

$\begin{array}{llll}2 & 35 & 15 & 353\end{array}$

$\begin{array}{llll}20 & 100 & 6 & 241\end{array}$

$\begin{array}{rrrr}16 & 57 & 28 & 323 \\ 4 & 18 & 20 & 113\end{array}$

$\begin{array}{rrrr}4 & 18 & 20 & 113 \\ 9 & 111 & 14 & 185\end{array}$

$\begin{array}{rrrr}9 & 111 & 14 & 185 \\ 8 & 47 & 46 & 763\end{array}$

Random effects model

754

Heterogeneity: $I^{2}=52 \%, \mathrm{~T}^{2}=0.2674, p=0.01$

5640

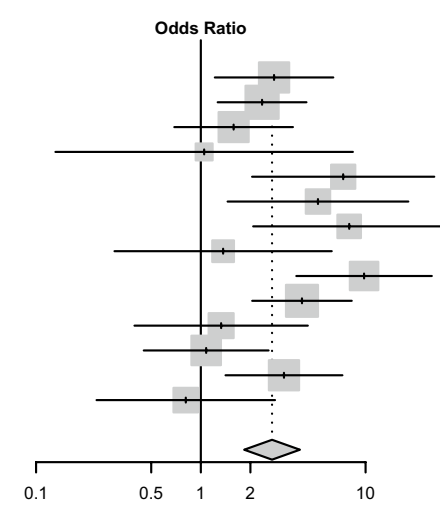

OR $\quad 95 \%-\mathrm{Cl}$ Weight

$2.78 \quad[1.22 ; 6.37] \quad 8.9 \%$

$2.35 \quad[1.27 ; 4.38] \quad 10.7 \%$

$1.58 \quad[0.69 ; 3.62] \quad 8.8 \%$

$1.05 \quad[0.13 ; 8.38] \quad 2.8 \%$

$7.31[2.05 ; 26.13] \quad 5.7 \%$

$5.14 \quad[1.45 ; 18.18] \quad 5.8 \%$

$7.96 \quad[2.08 ; 30.45] \quad 5.4 \%$

$1.37 \quad[0.30 ; 6.23] \quad 4.6 \%$

$9.79 \quad[3.80 ; 25.24] \quad 7.9 \%$

$4.11 \quad[2.05 ; 8.24] \quad 10.0 \%$

$\begin{array}{lll}1.33 & {[0.40 ; 4.46]} & 6.1 \% \\ 1.08 & {[0.45 ; 2.58]} & 8.5 \%\end{array}$

$3.20 \quad[1.41 ; 7.24] \quad 8.9 \%$

$0.81 \quad[0.23 ; 2.82] \quad 5.9 \%$

2.71 [1.83; 3.99] $100.0 \%$ 
4Fig. 2 Impact of age cut-offs on overall complications in patients undergoing laparoscopic cholecystectomy $\mathbf{A} \geq 60$ years $\mathbf{B} \geq 65$ years $\mathbf{C} \geq 70$ years $\mathbf{D} \geq 75$ years $\mathbf{E} \geq 80$ years

\section{Sensitivity analysis of adjusted outcomes}

Heterogeneity in the effect of increasing age on the reported outcomes was hypothesised to be due to the wide-range of age cut-offs used. Subgroup analyses of studies reporting only age cut-offs $\geq 70$ and $\geq 75$ were therefore completed.

\section{Discussion}

This systematic review and meta-analysis including 99 studies and 326,517 patients undergoing laparoscopic cholecystectomy demonstrated postoperative outcomes such as overall and major complications (Clavien-Dindo $\geq$ Grade III) were significantly higher in all age cut-offs. Further, this study demonstrated there is a sevenfold increase in perioperative mortality in the elderly compared to the nonelderly which increases by tenfold in patients $\geq 80$ years old. Although the risk of bile leak was higher in the overall cohort, there were no significant differences in bile leak in age cut-offs of $\geq 70$ and $\geq 80$ years old, respectively. There were significantly higher rates of conversions, as high as threefold in the elderly population. Patients converted from a minimally access surgery to open surgery have a higher risk of perioperative mortality and morbidity, as demonstrated in this review [18-20]. These findings were consistent even when stratified by urgency of surgery (i.e. elective or emergency). Whilst current risk estimation considers presence of comorbidities or American Society of Anaesthesiologist (ASA) grade, adopting risk profiles of varying age groups should also be considered during pre-operative counselling. Pre-operative optimisation of comorbidities, medications, screening for dementia and addressing frailty by a geriatrician or a full multi-disciplinary team could help improve operative outcomes in these patients [21-23].

The proportion of the population over the age of 65 is projected to rise from $18 \%$ currently to $25 \%$ in 30 years' time. Gallstone disease more commonly affects the elderly and in turn the sequelae of gallstone disease such as biliary colic, cholecystitis and pancreatitis make up a large aspect of acute surgical admissions. Current guidance advocates acute cholecystectomy within 1 week from the onset of acute cholecystitis and within 2 weeks if gallstones are the precipitant cause of pancreatitis [24]. Cholecystectomy in the acute setting has been shown to be both safe and cost effective [4, 25]. Increasing evidence also suggests superiority of cholecystectomy over cholecystostomy in high-risk patients [26, 27]. Patients undergoing cholecystostomy are predominantly elderly and up to a quarter of patients undergoing cholecystostomy will be re-admitted within 30 days of discharge [28]. Elderly patients undergoing cholecystostomy have been shown to have higher rates of mortality, postprocedural infection, bleeding and length of stay as compared to cholecystectomy [29]. These factors are changing the way we interpret and treat gallstone disease leading to a rise in the number of cholecystectomies performed each year. This highlights the importance in understanding and defining the impact of laparoscopic cholecystectomy on the elderly population.

This systematic review and meta-analysis adds evidence to quantify risk in elderly populations undergoing cholecystectomy. Increasingly healthcare professionals are questioned about discriminating against patients due to their age. It is often assumed that age is synonymous with increased co-morbidity. Due to lack of reporting in numerous studies, it was not possible to analyse age independently of co-morbidity. Future studies are increasingly adjusting for comorbidities and this is a potential area for enhancement in subsequent reviews. The meta-analysis is challenged by the lack of reporting of randomised and multicentre publications which is a further source of potential improvement with the publication of higher quality evidence. Despite some of the potential areas for improvement, this meta-analysis is the first to specifically quantify the postoperative risk of cholecystectomy in the elderly population. It encompasses a large number of studies which in turn incorporates over 300,000 patients. As the population ages, it is important that we improve our understanding of risk for elderly patients undergoing cholecystectomy and this meta-analysis makes significant strides to achieve this.

Consideration of alternative treatment strategies to laparoscopic in elderly patients will aid in informed-decision making amongst patients. In patients with acute cholecystitis, alternative strategies may include antibiotic management and percutaneous catheter drainage [30, 31]. A recent randomised controlled trial [26] comparing percutaneous catheter drainage and laparoscopic cholecystectomy for highrisk patients with acute cholecystitis identified laparoscopic cholecystectomy to be associated with significantly lower rates of major complications and re-interventions, although 
Table 2 Summary postoperative outcomes in elderly and nonelderly patients by urgency of laparoscopic cholecystectomy

\begin{tabular}{|c|c|c|c|c|c|}
\hline$\overline{\text { Outcomes }}$ & Studies, $n$ & Patients, $n$ & Odds ratio $(95 \% \mathrm{CI})$ & $p$ value & $I^{2}$ \\
\hline \multicolumn{6}{|c|}{ Overall complications } \\
\hline Elective & 10 & 4630 & $2.46(1.63-3.71)$ & $<0.001$ & 38 \\
\hline Emergency & 8 & 5396 & $1.98(1.33-2.94)$ & $<0.001$ & 48 \\
\hline Mixed & 24 & 36,324 & $2.27(1.83-2.82)$ & $<0.001$ & 52 \\
\hline \multicolumn{6}{|c|}{ Major complications } \\
\hline Elective & 1 & 284 & - & - & - \\
\hline Emergency & 1 & 152 & - & - & - \\
\hline Mixed & 10 & 33,058 & $1.81(1.47-2.21)$ & $<0.001$ & 35 \\
\hline \multicolumn{6}{|c|}{ Conversion to open } \\
\hline Elective & 9 & 4630 & $2.48(1.71-3.59)$ & $<0.001$ & 0 \\
\hline Emergency & 11 & 6414 & $2.28(1.39-3.75)$ & 0.001 & 58 \\
\hline Mixed & 27 & 44,069 & $2.09(1.67-2.63)$ & $<0.001$ & 69 \\
\hline \multicolumn{6}{|l|}{ Bile leaks } \\
\hline Elective & 4 & 442 & $0.56(0.12-2.69)$ & 0.5 & 0 \\
\hline Emergency & 8 & 5819 & $1.28(0.75-2.18)$ & 0.3 & 0 \\
\hline Mixed & 15 & 34,603 & $1.53(0.95-2.45)$ & 0.1 & 0 \\
\hline \multicolumn{6}{|c|}{ Postoperative mortality } \\
\hline Elective & 9 & 2595 & $13.34(2.07-85.92)$ & 0.006 & 0 \\
\hline Emergency & 11 & 6414 & $5.54(1.96-15.70)$ & 0.001 & 0 \\
\hline Mixed & 25 & 65,482 & $8.08(4.37-14.92)$ & $<0.001$ & 73 \\
\hline \multicolumn{6}{|c|}{ Length of stay, days } \\
\hline Elective & 4 & 752 & $1.84(1.27-2.41)$ & $<0.001$ & 64 \\
\hline Emergency & 7 & 1513 & $2.63(1.13-4.14)$ & $<0.001$ & 88 \\
\hline Mixed & 5 & 8020 & $1.99(0.44-3.54)$ & 0.012 & 99 \\
\hline
\end{tabular}

no significant difference in mortality rates. Whilst bridging with percutaneous catheter drainage prior to laparoscopic cholecystectomy may be a sensible treatment strategy, this needs to be evaluated in a case-by-case basis. However, alternative strategies for biliary colic and chronic cholecystitis are conservative options such as diet and weight control to reduce episodes of gallstone related complications. Nonetheless, careful discussion with patients on risks and benefits of laparoscopic cholecystectomy is warranted.

Our systematic review and meta-analysis do have some limitations to be addressed. Firstly, whilst it is a thorough review containing large patient numbers, the evidence comes from mainly retrospective case series and from studies which have used different age cut-offs. Secondly, chronological age has many limitations and data on biological fitness is lacking to explain why elderly patients develop poorer outcomes compared to younger patients [32]. For example, prospective scoring of patient frailty, an increasingly recognised feature associated with poor postoperative outcomes, is lacking [7, 33]. Thirdly, a precise scoring of intraoperative cholecystectomy difficulty is lacking [34, 35]. Elderly patients often have gallstones for many years and features of chronic cholecystitis with the obliteration of the tissue planes in Calot's triangle and even chronic fistulation, such as Mirizzi syndrome [36] or cholecysto-enteric fistulation, which naturally lead to poorer patient outcomes [37]. These challenging operative conditions require a modification in surgical strategies to ensure best patient outcomes [38]. Finally, whilst length of stay should ideally come with discharge to a nursing facility, it remains unclear from the included studies if this were the case and hence could not be evaluated. 


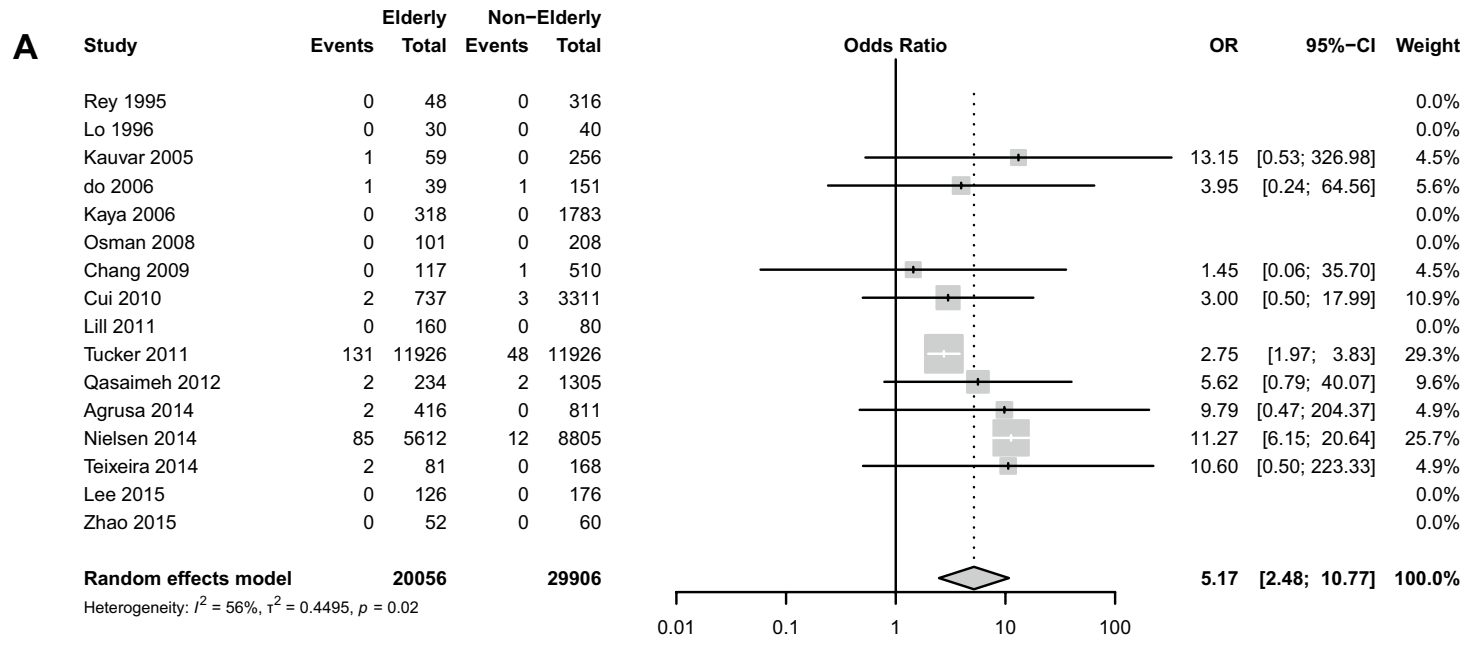

B Study

Paganini 2002

Bingener 2003

Annamaneni 2005

Yetkin 2009

Fujikawa 2012

Ambe 2015

Random effects mode

Heterogeneity: $I^{2}=0 \%, \mathrm{~T}^{2}=0, p=0.92$

Elderly Non-Elderly

Events Total Events Total

$\begin{array}{rrrr}1 & 77 & 0 & 207 \\ 5 & 230 & 1 & 165 \\ 0 & 29 & 0 & 17 \\ 0 & 68 & 0 & 527 \\ 0 & 49 & 0 & 62 \\ 2 & 74 & 0 & 78\end{array}$

527

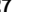

1056

Elderly Non-Elderly

C Study

Events Total Events Total

Firilas 1996

Pessaux 2000

Majeski 2004

Kirshtein 2008

Osman 2008

Polychronidis 2008

Su 2009

Lill 2011

Fuks 2015

$\begin{array}{rr}0 & 61 \\ 1 & 102 \\ 2 & 35 \\ 2 & 42 \\ 0 & 23 \\ 0 & 153 \\ 0 & 17 \\ 0 & 80 \\ 1 & 78\end{array}$

$\begin{array}{rr}2 & 133 \\ 0 & 761 \\ 0 & 47 \\ 1 & 183 \\ 0 & 286 \\ 0 & 2259 \\ 0 & 39 \\ 0 & 160 \\ 0 & 336\end{array}$

Random effects model

591

Heterogeneity: $I^{2}=2 \%, \mathrm{~T}^{2}=0.0483, p=0.39$

4204

Elderly Non-Elderly

D Study

Tagle 1997

Brunt 2001

Bingener 2003

Costi 2007

Pavlidis 2008

Chang 2009

Lee 2013

Agrusa 2014

Mauro 2014

Nielsen 2014

Peker 2014

Lee 2015

Wakasugi 2017

Yokota 2018

Events Total Events Total

Random effects model

Heterogeneity: $I^{2}=32 \%, \mathrm{~T}^{2}=0.4044, p=0.13$

$\begin{array}{rrrr}2 & 20 & 0 & 70 \\ 5 & 105 & 0 & 210 \\ 2 & 70 & 0 & 351\end{array}$

$\begin{array}{llll}2 & 70 & 0 & 351\end{array}$

$\begin{array}{rrrr}1 & 27 & 0 & 133 \\ 0 & 21 & 1 & 1242\end{array}$

$\begin{array}{llll}0 & 21 & 1 & 1242 \\ 0 & 17 & 1 & 610\end{array}$

$57 \quad 7 \quad 323$

$2 \quad 65 \quad 0 \quad 1162$

$\begin{array}{lllr}1 & 18 & 0 & 113\end{array}$

$\begin{array}{llll}44 & 697 & 53 & 13720\end{array}$

$\begin{array}{rrrr}1 & 111 & 2 & 185 \\ 0 & 35 & 0 & 267\end{array}$

$\begin{array}{llll}0 & 35 & 0 & 267 \\ 0 & 47 & 0 & 763\end{array}$

$\begin{array}{llll}0 & 52 & 0 & 299\end{array}$

1391

19794
Maxwell 1998

$\begin{array}{llll}1 & 49 & 5 & 346\end{array}$

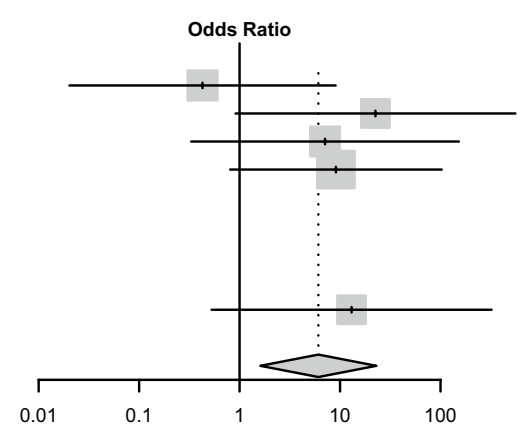

OR

$95 \%-\mathrm{Cl}$ Weight

$0.43 \quad[0.02 ; 9.04] \quad 18.6 \%$ $22.51 \quad[0.91 ; 556.21] \quad 16.9 \%$ $7.09 \quad[0.33 ; 152.48] \quad 18.4 \%$

$9.10[0.81 ; 102.82] \quad 29.2 \%$

$0.0 \%$
$0.0 \%$

$0.0 \%$
$0.0 \%$

$13.03 \quad[0.53 ; 322.81] \quad 16.9 \%$

$6.09[1.61 ; 23.02] 100.0 \%$

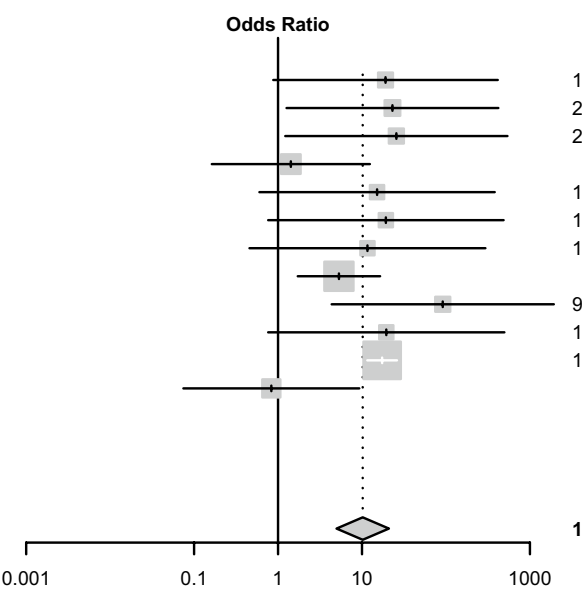

OR $\quad 95 \%-\mathrm{Cl}$ Weight

$19.05 \quad[0.88 ; 414.27] \quad 4.7 \%$

$23.04 \quad[1.26 ; 420.74] \quad 5.2 \%$

25.66 [ $1.22 ; 540.34] \quad 4.8 \%$

$1.42 \quad[0.16 ; 12.42] \quad 8.2 \%$

$15.11 \quad[0.60 ; 381.15] \quad 4.3 \%$

19.25 [ $0.76 ; 486.04] \quad 4.3 \%$

$11.61 \quad[0.46 ; 295.16] \quad 4.3 \%$

$5.31 \quad[1.72 ; 16.44] \quad 18.2 \%$

$91.54 \quad[4.35 ; 1926.73] \quad 4.8 \%$

$19.46 \quad[0.76 ; 496.79] \quad 4.3 \%$

$17.38 \quad[11.56 ; 26.11] \quad 30.0 \%$

$0.83 \quad[0.07 ; 9.28] \quad 7.0 \%$

$0.0 \%$

$0.0 \%$
$0.0 \%$

10.20 [ $4.97 ; 20.92] \quad 100.0 \%$

Fig. 3 Impact of age cut-offs on bile leaks in patients undergoing laparoscopic cholecystectomy $\mathbf{A} \geq 65$ years $\mathbf{B} \geq 70$ years $\mathbf{C} \geq 75$ years $\mathbf{D} \geq 80$ years 


\section{Conclusion}

Overall and major complications are significantly increased in the elderly following laparoscopic cholecystectomy. There is an associated sevenfold increase in perioperative mortality which increases to tenfold in patients $\geq 80$ years old group. This study confirms preconceived suspicions of higher risks in elderly patients undergoing cholecystectomy and will aid treatment planning and informed consent.

\section{Compliance with ethical standards}

Disclosures Dr Sivesh K Kamarajah has no conflicts of interest or financial ties to disclose. Dr Santhosh Karri has no conflicts of interest or financial ties to disclose. Dr James Bundred has no conflicts of interest or financial ties to disclose. Mr Richard PT Evans has no conflicts of interest or financial ties to disclose. Mr Aaron Lin has no conflicts of interest or financial ties to disclose. Miss Tania Kew has no conflicts of interest or financial ties to disclose. Miss Chinenye Ekeozor has no conflicts of interest or financial ties to disclose. Dr Susan L Powell has no conflicts of interest or financial ties to disclose. Mr Pritam Singh has no conflicts of interest or financial ties to disclose. Mr Ewen Griffiths has no conflicts of interest or financial ties to disclose.Dr Sivesh K Kamarajah has no conflicts of interest or financial ties to disclose. Dr Santhosh Karri has no conflicts of interest or financial ties to disclose. Dr James Bundred has no conflicts of interest or financial ties to disclose. Mr Richard PT Evans has no conflicts of interest or financial ties to disclose. Mr Aaron Lin has no conflicts of interest or financial ties to disclose. Miss Tania Kew has no conflicts of interest or financial ties to disclose. Miss Chinenye Ekeozor has no conflicts of interest or financial ties to disclose. Dr Susan L Powell has no conflicts of interest or financial ties to disclose. Mr Pritam Singh has no conflicts of interest or financial ties to disclose. Mr Ewen Griffiths has no conflicts of interest or financial ties to disclose.

Open Access This article is licensed under a Creative Commons Attribution 4.0 International License, which permits use, sharing, adaptation, distribution and reproduction in any medium or format, as long as you give appropriate credit to the original author(s) and the source, provide a link to the Creative Commons licence, and indicate if changes were made. The images or other third party material in this article are included in the article's Creative Commons licence, unless indicated otherwise in a credit line to the material. If material is not included in the article's Creative Commons licence and your intended use is not permitted by statutory regulation or exceeds the permitted use, you will need to obtain permission directly from the copyright holder. To view a copy of this licence, visit http://creativecommons.org/licenses/by/4.0/.

\section{References}

1. Wilson E, Gurusamy K, Gluud C, Davidson BR (2010) Costutility and value-of-information analysis of early versus delayed laparoscopic cholecystectomy for acute cholecystitis. Br J Surg 97(2):210-219

2. Uzzaman MM, Tayeh S, Sinha S, Ratnasingham K, Stoker DL (2011) Consenting practice for laparoscopic cholecystectomy: are we doing enough to warn patients about their operation? Int J Surg 9(8):643-647
3. CholeS Study Group (2016) Population-based cohort study of variation in the use of emergency cholecystectomy for benign gallbladder diseases. Br J Surg 103(12):1716-1726

4. Sutton AJ, Vohra RS, Hollyman M, Marriott PJ, Buja A, Alderson D, Pasquali S, Griffiths EA, Chole SS, the West Midlands Research (2017) Cost-effectiveness of emergency versus delayed laparoscopic cholecystectomy for acute gallbladder pathology. $\mathrm{Br}$ J Surg 104(1):98-107

5. Parmar KL, Law J, Carter B, Hewitt J, Boyle JM, Casey P, Maitra I, Farrell IS, Pearce L, Moug SJ, Group ELFS (2019) Frailty in older patients undergoing emergency laparotomy: results From the UK observational emergency laparotomy and frailty (ELF) study. Ann Surg. https://doi.org/10.1097/SLA.000000000000340 2

6. Hewitt J, Carter B, McCarthy K, Pearce L, Law J, Wilson FV, Tay HS, McCormack C, Stechman MJ, Moug SJ, Myint PK (2019) Frailty predicts mortality in all emergency surgical admissions regardless of age. An observational study. Age Ageing 48(3):388-394

7. Pisano M, Ceresoli M, Cimbanassi S, Gurusamy K, Coccolini F, Borzellino G, Costa G, Allievi N, Amato B, Boerma D, Calcagno P, Campanati L, Campanile FC, Casati A, Chiara O, Crucitti A, di Saverio S, Filauro M, Gabrielli F, Guttadauro A, Kluger Y, Magnone S, Merli C, Poiasina E, Puzziello A, Sartelli M, Catena F, Ansaloni L (2019) 2017 WSES and SICG guidelines on acute calcolous cholecystitis in elderly population. World J Emerg Surg 14:10

8. Mora-Guzman I, Di Martino M, Bonito AC, Jodra VV, Hernandez SG, Martin-Perez E (2019) Conservative management of gallstone disease in the elderly population: outcomes and recurrence. Scand J Surg 150:515-525

9. Arthur JD, Edwards PR, Chagla LS (2003) Management of gallstone disease in the elderly. Ann R Coll Surg Engl 85(2):91-96

10. Bingener J, Richards ML, Schwesinger WH, Strodel WE, Sirinek KR (2003) Laparoscopic cholecystectomy for elderly patients: gold standard for golden years? Arch Surg 138(5):531-535

11. Turrentine FE, Wang H, Simpson VB, Jones RS (2006) Surgical risk factors, morbidity, and mortality in elderly patients. J Am Coll Surg 203(6):865-877

12. Yetkin G, Uludag M, Oba S, Citgez B, Paksoy I (2009) Laparoscopic cholecystectomy in elderly patients. JSLS 13(4):587-591

13. Liberati A, Altman DG, Tetzlaff J, Mulrow C, Gotzsche PC, Ioannidis JP, Clarke M, Devereaux PJ, Kleijnen J, Moher D (2009) The PRISMA statement for reporting systematic reviews and meta-analyses of studies that evaluate healthcare interventions: explanation and elaboration. BMJ 339:b2700

14. Clavien PA, Barkun J, de Oliveira ML, Vauthey JN, Dindo D, Schulick RD, de Santibanes E, Pekolj J, Slankamenac K, Bassi C, Graf R, Vonlanthen R, Padbury R, Cameron JL, Makuuchi M (2009) The Clavien-Dindo classification of surgical complications: five-year experience. Ann Surg 250(2):187-196

15. Sterne JA, Hernan MA, Reeves BC, Savovic J, Berkman ND, Viswanathan M, Henry D, Altman DG, Ansari MT, Boutron I, Carpenter JR, Chan AW, Churchill R, Deeks JJ, Hrobjartsson A, Kirkham J, Juni P, Loke YK, Pigott TD, Ramsay CR, Regidor D, Rothstein HR, Sandhu L, Santaguida PL, Schunemann HJ, Shea B, Shrier I, Tugwell P, Turner L, Valentine JC, Waddington H, Waters E, Wells GA, Whiting PF, Higgins JP (2016) ROBINS-I: a tool for assessing risk of bias in non-randomised studies of interventions. BMJ 355:i4919

16. Kamarajah SK, Bundred J, Tan BHL (2019) Body composition assessment and sarcopenia in patients with gastric cancer: a systematic review and meta-analysis. Gastric Cancer 22(1):10-22

17. Kamarajah SK, Sutandi N, Robinson SR, French JJ, White SA (2019) Robotic versus conventional laparoscopic distal 
pancreatic resection: a systematic review and meta-analysis. HPB (Oxford) 46:6-14

18. Franko J, O'Connell BG, Mehall JR, Harper SG, Nejman JH, Zebley DM, Fassler SA (2006) The influence of prior abdominal operations on conversion and complication rates in laparoscopic colorectal surgery. JSLS 10(2):169-175

19. Tekkis PP, Senagore AJ, Delaney CP (2005) Conversion rates in laparoscopic colorectal surgery: a predictive model with, 1253 patients. Surg Endosc 19(1):47-54

20. Sutcliffe RP, Hollyman M, Hodson J, Bonney G, Vohra RS, Griffiths EA, CholeS Study Group (2016) Preoperative risk factors for conversion from laparoscopic to open cholecystectomy: a validated risk score derived from a prospective UK database of 8820 patients. HPB (Oxford) 18(11):922-928

21. Braude P, Goodman A, Elias T, Babic-Illman G, Challacombe B, Harari D, Dhesi JK (2017) Evaluation and establishment of a ward-based geriatric liaison service for older urological surgical patients: proactive care of Older People undergoing Surgery (POPS)-Urology. BJU Int 120(1):123-129

22. Partridge J, Sbai M, Dhesi J (2018) Proactive care of older people undergoing surgery. Aging Clin Exp Res 30(3):253-257

23. Harari D, Hopper A, Dhesi J, Babic-Illman G, Lockwood L, Martin F (2007) Proactive care of older people undergoing surgery ('POPS'): designing, embedding, evaluating and funding a comprehensive geriatric assessment service for older elective surgical patients. Age Ageing 36(2):190-196

24. Association of Upper Gastrointestinal Surgeons of Great, B. Commissioning Guide: Gallstone Disease; 01/02/2016, 2016; p 16.

25. de Mestral C, Hoch JS, Laupacis A, Wijeysundera HC, Rotstein OD, Alali AS, Nathens AB (2016) Early cholecystectomy for acute cholecystitis offers the best outcomes at the least cost: a model-based cost-utility analysis. J Am Coll Surg 222(2):185-194

26. Loozen CS, van Santvoort HC, van Duijvendijk P, Besselink MG, Gouma DJ, Nieuwenhuijzen GA, Kelder JC, Donkervoort SC, van Geloven AA, Kruyt PM, Roos D, Kortram K, Kornmann VN, Pronk A, van der Peet DL, Crolla RM, van Ramshorst B, Bollen TL, Boerma D (2018) Laparoscopic cholecystectomy versus percutaneous catheter drainage for acute cholecystitis in high risk patients (CHOCOLATE): multicentre randomised clinical trial. BMJ 363:k3965

27. Hall BR, Armijo PR, Krause C, Burnett T, Oleynikov D (2018) Emergent cholecystectomy is superior to percutaneous cholecystostomy tube placement in critically ill patients with emergent calculous cholecystitis. Am J Surg 216(1):116-119

28. Fleming MM, Liu F, Luo J, Zhang Y, Pei KY (2019) Predictors of 30 day readmission following percutaneous cholecystostomy. J Surg Res 233:1-7

29. Schlottmann F, Gaber C, Strassle PD, Patti MG, Charles AG (2019) Cholecystectomy vs cholecystostomy for the management of acute cholecystitis in elderly patients. J Gastrointest Surg 23(3):503-509

30. Sanjay P, Mittapalli D, Marioud A, White RD, Ram R, Alijani A (2013) Clinical outcomes of a percutaneous cholecystostomy for acute cholecystitis: a multicentre analysis. HPB (Oxford) 15(7):511-516

31. Jang WS, Lim JU, Joo KR, Cha JM, Shin HP, Joo SH (2015) Outcome of conservative percutaneous cholecystostomy in highrisk patients with acute cholecystitis and risk factors leading to surgery. Surg Endosc 29(8):2359-2364

32. Lasithiotakis K, Petrakis J, Venianaki M, Georgiades G, Koutsomanolis D, Andreou A, Zoras O, Chalkiadakis G (2012) Frailty predicts outcome of elective laparoscopic cholecystectomy in geriatric patients. Surg Endosc 27(4):1144-1150
33. Kenig J, Walega P, Olszewska U, Konturek A, Nowak W (2016) Geriatric Assessment as a qualification element for elective and emergency cholecystectomy in older patients. World J Emerg Surg 11:36

34. Griffiths EA, Hodson J, Vohra RS, Marriott P, Katbeh T, Zino S, Nassar AHM, CholeS Study Group (2019) Correction to: utilisation of an operative difficulty grading scale for laparoscopic cholecystectomy. Surg Endosc 33(1):122-125

35. Griffiths EA, Hodson J, Vohra RS, Marriott P, Katbeh T, Zino S, Nassar AHM, West Midlands Research (2019) Utilisation of an operative difficulty grading scale for laparoscopic cholecystectomy. Surg Endosc 33(1):110-121

36. Kulkarni SS, Hotta M, Sher L, Selby RR, Parekh D, Buxbaum J, Stapfer M (2017) Complicated gallstone disease: diagnosis and management of Mirizzi syndrome. Surg Endosc 31(5):2215-2222

37. Beltran MA, Csendes A, Cruces KS (2008) The relationship of Mirizzi syndrome and cholecystoenteric fistula: validation of a modified classification. World J Surg 32(10):2237-2243

38. Strasberg SM, Pucci MJ, Brunt LM, Deziel DJ (2016) Subtotal cholecystectomy-"fenestrating" vs "reconstituting" subtypes and the prevention of bile duct injury: definition of the optimal procedure in difficult operative conditions. J Am Coll Surg 222(1):89-96

39. Schreiber H, Macon WL, Pories WJ (1978) Incidental cholecystectomy during major abdominal surgery in the elderly. Am $\mathrm{J}$ Surg 135(2):196-198

40. Loureiro ER, Klein SC, Pavan CC, Almeida LD, da Silva FH, Paulo DN (2011) Laparoscopic cholecystectomy in 960 elderly patients. Rev Col Bras Cir 38(3):155-160

41. Houghton PW, Jenkinson LR, Donaldson LA (1985) Cholecystectomy in the elderly: a prospective study. Br J Surg 72(3):220-222

42. Amato G, Salamone G, Romano G, Agrusa A, Saladino V, Gulotta G (2010) Open mini-invasive cholecystectomy in high risk elderly A review of 121 consecutive procedures. G Chir 31(11-12):518-522

43. Pigott JP, Williams GB (1988) Cholecystectomy in the elderly. Am J Surg 155(3):408-410

44. Saxe A, Lawson J, Phillips E (1993) Laparoscopic cholecystectomy in patients aged 65 or older. J Laparoendosc Surg 3(3):215-219

45. Askew AR (1995) Surgery for gallstones in the elderly. ANZ J Surg 65(5):312-315

46. Escarce JJ, Shea JA, Chen W, Qian Z, Schwartz JS (1995) Outcomes of open cholecystectomy in the elderly: a longitudinal analysis of 21,000 cases in the prelaparoscopic era. Surgery 117(2):156-164

47. Lujan JA, Sanchez-Bueno F, Parrilla P, Robles R, Torralba JA, Gonzalez-Costea R (1998) Laparoscopic vs open cholecystectomy in patients aged 65 and older. Surg Laparosc Endosc 8(3):208-210

48. Wang YC, Yang HR, Chung PK, Jeng LB, Chen RJ (2006) Role of fundus-first laparoscopic cholecystectomy in the management of acute cholecystitis in elderly patients. J Laparoendosc Adv Surg Tech A 16(2):124-127

49. Malik AM, Laghari AA, Talpur KA, Memon A, Pathan R, Memon JM (2007) Laparoscopic cholecystectomy in the elderly patients. An experience at Liaquat University Hospital Jamshoro. J Ayub Med Coll Abbottabad 19(4):45-48

50. Cheng SP, Chang YC, Liu CL, Yang TL, Jeng KS, Lee JJ, Liu TP (2008) Factors associated with prolonged stay after laparoscopic cholecystectomy in elderly patients. Surg Endosc 22(5):1283-1289

51. Lasithiotakis K, Petrakis J, Venianaki M, Georgiades G, Koutsomanolis D, Andreou A, Zoras O, Chalkiadakis G (2013) 
Frailty predicts outcome of elective laparoscopic cholecystectomy in geriatric patients. Surg Endosc 27(4):1144-1150

52. Cull JD, Velasco JM, Czubak A, Rice D, Brown EC (2014) Management of acute cholecystitis: prevalence of percutaneous cholecystostomy and delayed cholecystectomy in the elderly. $\mathbf{J}$ Gastrointest Surg 18(2):328-333

53. Ferrarese AG, Solej M, Enrico S, Falcone A, Catalano S, Pozzi G, Marola S, Martino V (2013) Elective and emergency laparoscopic cholecystectomy in the elderly: our experience. BMC Surg 13(Suppl 2):S21

54. Rao A, Polanco A, Qiu S, Kim J, Chin EH, Divino CM, Nguyen SQ (2013) Safety of outpatient laparoscopic cholecystectomy in the elderly: analysis of 15,248 patients using the NSQIP database. J Am Coll Surg 217(6):1038-1043

55. Rubert CP, Higa RA, Farias FV (2016) Comparison between open and laparoscopic elective cholecystectomy in elderly, in a teaching hospital. Rev Col Bras Cir 43(1):2-5

56. Zeren S (2017) Bridge treatment for early cholecystectomy in geriatric patients with acute cholecystitis; percutaneous cholecystostomy. Turk J Trauma Emerg Surg 23:501-506

57. Huber DF, Martin EW Jr, Cooperman M (1983) Cholecystectomy in elderly patients. Am J Surg 146(6):719-722

58. Margiotta SJ Jr, Horwitz JR, Willis IH, Wallack MK (1988) Cholecystectomy in the elderly. Am J Surg 156(6):509-512

59. Watemberg S, Landau O, Avrahami R, Nudelman IL, Reiss $\mathrm{R}$ (1997) Incidental cholecystectomy in the over-70 age group. A 19-year retrospective, comparative study. Int Surg 82(1):102-104

60. Montori A, Boscaini M, Gasparrini M, Miscusi G, Masoni L, Onorato M, Montori J (2000) Gallstones in elderly patients: impact of laparoscopic cholecystectomy. Can J Gastroenterol 14(11):929-932

61. Fisichella PM, Di Stefano A, Di Carlo I, La Greca G, Russello D, Latteri F (2002) Efficacy and safety of elective laparoscopic cholecystectomy in elderly: a case-controlled comparison with the open approach. Ann Ital Chir 73(2):149-153

62. Zappulla E, Russo V, Gullotta I, Patanè G, Trovato S, Lucifora B, Costa S, Tracia A, Caglià P, Amodeo C (2009) Laparoscopic cholecystectomy in the elderly. BMC Geriatrics 9(1):A11

63. Caglia P, Costa S, Tracia A, Veroux M, Luca S, Zappulla E, Russo V, Lucifora B, Borzi L, Patane G, Trovato S, Amodeo C (2012) Can laparoscopic cholecystectomy be safety performed in the elderly? Ann Ital Chir 83(1):21-24

64. Aprea G, Rocca A, Salzano A, Sivero L, Scarpaleggia M, Ocelli P, Amato M, Bianco T, Serra R, Amato B (2016) Laparoscopic single site (LESS) and classic video-laparoscopic cholecystectomy in the elderly: a single centre experience. Int J Surg 33(Suppl 1):S1-3

65. Mastalerz K, Kenig J, Olszewska U, Michalik C (2018) The Surgical Apgar score and frailty as outcome predictors in short- and long-term evaluation of fit and frail older patients undergoing elective laparoscopic cholecystectomy: a prospective cohort study. Videosurg Other Miniinvas Tech 13(3):350-357

66. Decker G, Goergen M, Philippart P, Mendes da Costa P (2001) Laparoscopic cholecystectomy for acute cholecystitis in geriatric patients. Acta Chir Belg 101(6):294-299

67. Pessaux P, Regenet N, Tuech JJ, Rouge C, Bergamaschi R, Arnaud JP (2001) Laparoscopic versus open cholecystectomy: a prospective comparative study in the elderly with acute cholecystitis. Surg Laparosc Endosc Percutan Tech 11(4):252-255

68. Chau CH, Tang CN, Siu WT, Ha JP, Li MK (2002) Laparoscopic cholecystectomy versus open cholecystectomy in elderly patients with acute cholecystitis: retrospective study. Hong Kong Med J 8(6):394-399
69. Coenye KE, Jourdain S, Mendes da Costa P (2005) Laparoscopic cholecystectomy for acute cholecystitis in the elderly: a retrospective study. Hepatogastroenterology 52(61):17-21

70. Moyson J, Thill V, Simoens C, Smets D, Debergh N, MendesdaCosta P (2008) Laparoscopic cholecystectomy for acute cholecystitis in the elderly: a retrospective study of 100 patients. Hepatogastroenterology 55(88):1975-1980

71. Maxwell JG, Tyler BA, Rutledge R, Brinker CC, Maxwell BG, Covington DL (1998) Cholecystectomy in patients aged 80 and older. Am J Surg 176(6):627-631

72. Uecker J, Adams M, Skipper K, Dunn E (2001) Cholecystitis in the octogenarian: is laparoscopic cholecystectomy the best approach? Am Surg 67(7):637-640

73. Hazzan D, Geron N, Golijanin D, Reissman P, Shiloni E (2003) Laparoscopic cholecystectomy in octogenarians. Surg Endosc 17(5):773-776

74. Tambyraja AL, Kumar S, Nixon SJ (2004) Outcome of laparoscopic cholecystectomy in patients 80 years and older. World $\mathrm{J}$ Surg 28(8):745-748

75. Tambyraja AL, Kumar S, Nixon SJ (2005) POSSUM scoring for laparoscopic cholecystectomy in the elderly. ANZ J Surg 75(7):550-552

76. Leandros E, Alexakis N, Archontovasilis F, Albanopoulos K, Dardamanis D, Menenakos E, Tsigris C, Giannopoulos A (2007) Outcome analysis of laparoscopic cholecystectomy in patients aged 80 years and older with complicated gallstone disease. J Laparoendosc Adv Surg Tech A 17(6):731-735

77. Marcari RS, Lupinacci RM, Nadal LR, Rego RE, Coelho AM, de Matos Farah JF (2012) Outcomes of laparoscopic cholecystectomy in octogenarians. JSLS 16(2):271-275

78. Lupinacci RM, Nadal LR, Rego RE, Dias AR, Marcari RS, Lupinacci RA, Farah JF (2013) Surgical management of gallbladder disease in the very elderly: are we operating them at the right time? Eur J Gastroenterol Hepatol 25(3):380-384

79. Wiggins T, Markar SR, Mackenzie H, Jamel S, Askari A, Faiz O, Karamanakos S, Hanna GB (2018) Evolution in the management of acute cholecystitis in the elderly: population-based cohort study. Surg Endosc 32(10):4078-4086

80. Dubecz A, Langer M, Stadlhuber RJ, Schweigert M, Solymosi N, Feith M, Stein HJ (2012) Cholecystectomy in the very elderly: is 90 the new 70? J Gastrointest Surg 16(2):282-285

81. Irojah B (2017) Are they too old for surgery? safety of cholecystectomy in superelderly patients ( $\geq$ age 90 ). Permanente J. https ://doi.org/10.7812/TPP/16-013

82. Mayol J, Martinez-Sarmiento J, Tamayo FJ, Alvarez FernÁNdezRepresa J (1997) Complications of laparoscopic cholecystectomy in the ageing patient. Age Ageing 26(2):77-81

83. Yetim I, Dervisoglu A, Karakose O, Buyukkaraba-Cak Y, Bek Y, Erzurumlu K (2010) Is advanced age a significant risk factor for laparoscopic cholecystectomy? Minerva Chir 65(5):507-513

84. Nazeer MA, Ali M, Ahmed K, Saleem R (2012) Outcomes of Laparoscopic Cholecystectomy in the elderly versus young patients. PJMHS 6(3):544-546

85. Bhandari TR, Shahi S, Bhandari R, Poudel R (2017) Laparoscopic cholecystectomy in the elderly: an experience at a tertiary care hospital in western Nepal. Surg Res Pract 2017:8204578

86. Ekici U, Yilmaz S, Tatli F (2018) Comparative analysis of laparoscopic cholecystectomy performed in the elderly and younger patients: should we abstain from laparoscopic cholecystectomy in the elderly? Cureus 10(6):e2888

87. Rey S, Yamakawa T, Kano N, Ishikawa Y, Hakeem R, Sha M, Koishi K (1995) Laparoscopic cholecystectomy: treatment of choice in elderly patients. Dig Endosc 7(4):350-352

88. Firilas A, Duke BE, Max MH (1996) Laparoscopic cholecystectomy in the elderly. Surg Endosc 10(1):33-35 
89. Lo CM, Lai EC, Fan ST, Liu CL, Wong J (1996) Laparoscopic cholecystectomy for acute cholecystitis in the elderly. World J Surg 20(8):983-986

90. Tagle FM, Lavergne J, Barkin JS, Unger SW (1997) Laparoscopic cholecystectomy in the elderly. Surg Endosc 11(6):636-638

91. Brunt LM, Quasebarth MA, Dunnegan DL, Soper NJ (2001) Outcomes analysis of laparoscopic cholecystectomy in the extremely elderly. Surg Endosc 15(7):700-705

92. Majeski J (2004) Laparoscopic cholecystectomy in geriatric patients. Am J Surg 187(6):747-750

93. Annamaneni RK, Moraitis D, Cayten CG (2005) Laparoscopic cholecystectomy in the elderly. JSLS 9(4):408-410

94. Kauvar DS, Brown BD, Braswell AW, Harnisch M (2005) Laparoscopic cholecystectomy in the elderly: increased operative complications and conversions to laparotomy. J Laparoendosc Adv Surg Tech A 15(4):379-382

95. do Amaral PC, Azaro Filho Ede M, Galvao TD, Ettinger JE, Silva Reis JM, Lima M, Fahel E (2006) Laparoscopic cholecystectomy for acute cholecystitis in elderly patients. JSLS 10(4):479-483

96. Kwon AH, Matsui Y (2006) Laparoscopic cholecystectomy in patients aged 80 years and over. World J Surg 30(7):1204-1210

97. Kaya IO, Ozkardes A, Ozdemir F, Seker G, Tokac M, Ozmen MM (2008) Laparoscopic cholecystectomy in elderly people: does advanced age present any risk for conversion? J Am Geriatr Soc 56(5):962-963

98. Osman Y, Ebru M, Umit T, Volkan O, Melih K, Belma K, Betul B, Omer C, Atilla S (2008) Laparoscopic cholecystectomy in elderly patients. Bratisl Lek Listy 109(7):313-316

99. Chang WT, Yu FJ, Hsieh MY, Huang MC, Lee KT, Chen JS, Kuo KK, Chuang SC, Wang SR, Ker CG (2009) Laparoscopic cholecystectomy in aged patients. Hepatogastroenterology 56(93):950-955

100. Kim HO, Yun JW, Shin JH, Hwang SI, Cho YK, Son BH, Yoo CH, Park YL, Kim H (2009) Outcome of laparoscopic cholecystectomy is not influenced by chronological age in the elderly. World J Gastroenterol 15(6):722

101. Cui W, Zhang RY, Sun DQ, Gong RH, Han TQ (2010) Early laparoscopic cholecystectomy for acute gallbladder disease in Chinese elderly. Hepatogastroenterology 57(99-100):409-413

102. Yetim I (2011) Results in patients with different age groups laparoscopic cholecystectomy. J Clin Anal Med 2(3):75-78

103. Tucker JJ, Yanagawa F, Grim R, Bell T, Ahuja V (2011) Laparoscopic cholecystectomy is safe but underused in the elderly. Am Surg 77(8):1014-1020

104. Qasaimeh GR, Banihani MN (2012) Laparoscopic cholecystectomy in the elderly and young: a comparative study. Hepatogastroenterology 59(113):22-25

105. Agrusa A, Romano G, Frazzetta G, Chianetta D, Sorce V, Di Buono G, Gulotta G (2014) Role and outcomes of laparoscopic cholecystectomy in the elderly. Intl J Surg 12:S37-S39

106. Nielsen LBJ, Harboe KM, Bardram L (2013) Cholecystectomy for the elderly: no hesitation for otherwise healthy patients. Surg Endosc 28(1):171-177

107. Teixeira JP, Ribeiro C, Pinho A, Graca L, Moreira LM, Maia JC (2014) Laparoscopic cholecystectomy in acute cholecystitis in the elderly. Hepatogastroenterology 61(129):18-21

108. Zhao HQ, Liu HR, Xiao L, Zheng F, Li WM (2015) Laparoscopic cholecystectomy in elderly patients: an evaluation of immunity. Aging Clin Exp Res 27(6):927-933

109. Rizzuto A, Serra R, Mignogna C, Palaia I, Zittel FU, Sacco R (2016) Single incision laparoscopic cholecystectomy in geriatric patients. Int J Surg 35:83-87

110. Ido K, Suzuki T, Kimura K, Taniguchi Y, Kawamoto C, Isoda N, Nagamine N, Ioka T, Kumagai M (1995) Laparoscopic cholecystectomy in the elderly: analysis of pre-operative risk factors and postoperative complications. J Gastroenterol Hepatol 10(5):517-522

111. Paganini AM, Feliciotti F, Guerrieri M, Tamburini A, Campagnacci R, Lezoche E (2002) Laparoscopic cholecystectomy and common bile duct exploration are safe for older patients. Surg Endosc 16(9):1302-1308

112. Fujikawa T, Tada S, Abe T, Yoshimoto Y, Maekawa H, Shimoike N, Tanaka A, Fujikawa T, Tada S, Abe T, Yoshimoto Y, Maekawa H, Shimoike N, Tanaka A (2012) Is early laparoscopic cholecystectomy feasible for acute cholecystitis in the elderly? J Gastroenterol Hepatol Res 1(10):247-251

113. Ambe PC, Weber SA, Christ H, Wassenberg D (2015) Primary cholecystectomy is feasible in elderly patients with acute cholecystitis. Aging Clin Exp Res 27(6):921-926

114. Pessaux P, Tuech JJ, Derouet N, Rouge C, Regenet N, Arnaud JP (2000) Laparoscopic cholecystectomy in the elderly: a prospective study. Surg Endosc 14(11):1067-1069

115. Kirshtein B, Bayme M, Bolotin A, Mizrahi S, Lantsberg L (2008) Laparoscopic cholecystectomy for acute cholecystitis in the elderly: is it safe? Surg Laparosc Endosc Percutan Tech 18(4):334-339

116. Polychronidis A, Botaitis S, Tsaroucha A, Tripsianis G, Bounovas A, Pitiakoudis M, Simopoulos C (2008) Laparoscopic cholecystectomy in elderly patients. J Gastrointestin Liver Dis 17(3):309-313

117. Su HY, Lee WJ (2009) Laparoscopic cholecystectomy in older patients: clinical experience from 56 consecutive patients in a rural community hospital in Taiwan. Surg Laparosc Endosc Percutan Tech 19(3):227-230

118. Lill S, Rantala A, Vahlberg T, Grönroos JM (2011) Elective laparoscopic cholecystectomy: the effect of age on conversions complications and long-term results. Digestive Surgery 28(3):205-209

119. Fuks D, Duhaut P, Mauvais F, Pocard M, Haccart V, Paquet J-C, Millat B, Msika S, Sielezneff I, Scotté M, Chatelain D, Regimbeau JM (2015) A retrospective comparison of older and younger adults undergoing early laparoscopic cholecystectomy for mild to moderate calculous cholecystitis. J Am Geriatr Soc 63(5):1010-1016

120. Maxwell JG, Tyler BA, Maxwell BG, Brinker CC, Covington DL (1998) Laparoscopic cholecystectomy in octogenarians. Am Surg 64(9):826-831

121. Costi R, DiMauro D, Mazzeo A, Boselli AS, Contini S, Violi V, Roncoroni L, Sarli L (2007) Routine laparoscopic cholecystectomy after endoscopic sphincterotomy for choledocholithiasis in octogenarians: is it worth the risk? Surg Endosc 21(1):41-47

122. Pavlidis TE, Marakis GN, Symeonidis N, Psarras K, Ballas K, Rafailidis S, Sakantamis AK (2008) Considerations concerning laparoscopic cholecystectomy in the extremely elderly. J Laparoendosc Adv Surg Tech A 18(1):56-60

123. Leardi S, De Vita F, Pietroletti R, Simi M (2009) Cholecystectomy for gallbladder disease in elderly aged 80 years and over. Hepatogastroenterology 56(90):303-306

124. Lee W (2013) Cholecystectomy in octogenarians: recent 5 years' experience. Kor J Hepato-Biliary-Pancreatic Surg 17(4):162

125. Mauro DD, Faraci R, Mariani L, Cudazzo E, Costi R (2014) Rendezvous technique for cholecystocholedochal lithiasis in octogenarians: is it as effective as in younger patients, or should endoscopic sphincterotomy followed by laparoscopic cholecystectomy be preferred? J Laparoendosc Adv Surg Tech 24(1):13-21

126. Peker Y, Unalp HR, Durak E, Karabuga T, Yilmaz Y, Genc H, Haciyanli M (2014) Laparoscopic cholecystectomy in patients aged 80 years and older: an analysis of 111 patients. Surg Laparosc Endosc Percutan Tech 24(2):173-176 
127. Lee SI, Na BG, Yoo YS, Mun SP, Choi NK (2015) Clinical outcome for laparoscopic cholecystectomy in extremely elderly patients. Ann Surg Treat Res 88(3):145-151

128. Palsson S, Saliba G, Sandblom G (2016) Outcome after cholecystectomy in the elderly: a population-based register study. Scand J Gastroenterol 51(8):974-978

129. Wakasugi M, Tanemura M, Furukawa K, Tei M, Suzuki Y, Masuzawa T, Kishi K, Akamatsu H (2017) Feasibility and safety of single-incision laparoscopic cholecystectomy in elderly patients: a single institution, retrospective case series. Ann Med Surg (Lond) 22:30-33

130. Novello M, Gori D, Di Saverio S, Bianchin M, Maestri L, Mandarino FV, Cavallari G, Nardo B (2017) How safe is performing cholecystectomy in the oldest old? A 15-year retrospective study from a single institution. World J Surg 42(1):73-81
131. Yokota Y, Tomimaru Y, Noguchi K, Noda T, Hatano H, Nagase H, Hamabe A, Hirota M, Oshima K, Tanida T, Morita S, Imamura H, Iwazawa T, Akagi K, Dono K (2019) Surgical outcomes of laparoscopic cholecystectomy for acute cholecystitis in elderly patients. Asian J Endosc Surg 12(2):157-161

132. Priego Jimenez P, Ruiz-Tovar J, Ramiro C, Molina JM, Morales V, Lobo E (2014) Outcome of laparoscopic cholecystectomy in patients 85 years and older. Am Surg 80(11):E290-E292

Publisher's Note Springer Nature remains neutral with regard to jurisdictional claims in published maps and institutional affiliations.

\section{Affiliations}

\section{Sivesh K. Kamarajah ${ }^{1,2}$ - Santhosh Karri ${ }^{3}$. James R. Bundred ${ }^{3} \cdot$ Richard P. T. Evans $^{4,5} \cdot$ Aaron Lin $^{3} \cdot$ Tania Kew $^{3}$. Chinenye Ekeozor ${ }^{3} \cdot$ Susan L. Powell ${ }^{6}$ Pritam Singh ${ }^{7,8} \cdot$ Ewen A. Griffiths $^{4,5}$}

1 Department of Hepatobiliary, Pancreatic and Transplant Surgery, Freeman Hospital, Newcastle University NHS Foundation Trust Hospitals, Newcastle Upon Tyne, UK

2 Institute of Cellular Medicine, University of Newcastle, Newcastle Upon Tyne, UK

3 College of Medical and Dental Sciences, University of Birmingham, Birmingham, UK

4 Department of Upper Gastrointestinal Surgery, Queen Elizabeth Hospital Birmingham, University Hospitals Birmingham NHS Foundation Trust, Area 6, 7th Floor, Mindelsohn Way, Edgbaston, Birmingham B15 2WB, UK
5 Institute of Cancer and Genomic Sciences, College of Medical and Dental Sciences, University of Birmingham, Birmingham, UK

6 Department of Geriatric Medicine, Solihull Hospital, University Hospitals Birmingham NHS Foundation Trust, Birmingham, UK

7 Trent Oesophago-Gastric Unit, City Hospital Campus, Nottingham University Hospitals NHS Trust, Hucknall Road, Nottingham NG5 1PB, UK

8 Regional Oesophago-Gastric Unit, Royal Surrey County Hospital NHS Foundation Trust, Egerton Road, Guildford GU2 7XX, UK 